\title{
UDC 130.2:[7.041:7.044]
}

\section{O. M. GONCHAROVA ${ }^{1^{*}}$}

${ }^{1 *}$ Kyiv National University of Culture and Arts (Kyiv, Ukraine), e-mail o.m_goncharova@yahoo.com, ORCID 0000-0002-8649-9361

\section{ANTHROPOLOGY OF VISUAL SELF-OBJECTIFICATION OF THE PAINTER (BASED ON WORKS BY ARTEMISIA GENTILESCHI)}

Purpose. Based on the anthropocentric approach to the analysis of visual self-presentations of Artemisia Gentileschi in paintings, to present the artwork as self-objectifications of the artist, which give rise to a new cultural reality and are at the same time a means of knowing the essence of man. Theoretical basis. The principles and methods of philosophical and anthropological research in combination with biographical, historical and comparative, iconographic, figurative and stylistic methods were used when writing the article. Among philosophical and anthropological methods the principle of anthropological reduction was used, based on which the works by Artemisia Gentileschi were analyzed as her self-objectification, principle of extrapolation of a separate fact (rape) of the painter's life and anthropological interpretation of art evolution, when an attempt is made to know their creator through a series of chronological consistent works as figurative objectification. The biographical method was used when working with data on the painter's life, iconographic and figurative stylistic (techniques of composition, narrative, color characteristics) - when analyzing the art visuals: self-portraits, allegories and narrative paintings. The analytical work was carried out in stages as transition from an iconographic interpretation of paintings with gradual elimination of art and style characteristics as extra-anthropological cultural constants with subsequent anthropological reduction of cultural image. Originality consists in the author's method of analyzing the works of visual art in terms of anthropocentric approach, as well as in considering the artwork by Artemisia Gentileschi as her self-objectification as such that give rise to a new cultural reality. Conclusions. The artworks by Artemisia Gentileschi in diachronic deployment can be seen as the painter's self-objectification, which traces the evolution of self-expression from a person with traditional self-perception by social gender stereotypes (1610) to the phenomenon of personal life, which will determine further evolution of her self-identification (rape in 1611) and extirpation of sense of shame through virtual revenge (self-expression in the cycle of Judith), repentance (cycle of Mary Magdalene), guilt (cycle of Lucretia), and formation of component of the painter's identity as exemption from social gender prejudices and stereotypes on roles and standards of behavior socially assigned to women (cycle of Susanna).

Keywords: Artemisia Gentileschi; painter's self-objectification; visual self-presentation in painting; anthropocentric approach; man; the principle of anthropological reduction; organon-principle; anthropological interpretation; the principle of "open question"

\section{Introduction}

The heuristic potential of philosophical anthropology is not fully reached yet. The traditional limitation of philosophical discourse as purely theoretical does not, in my opinion, contribute to the wider application of those possibilities, which, in particular, peculiar to anthropology as a methodology. Meanwhile, its application is able to open new horizons of knowledge of human dimension both of the present and the future, as well as of the past.

In contrast to the socio-philosophical approach, which seeks to explain the essence of man from external factors, philosophical anthropology seeks to analyse cultural reality, based on man as such.

Otto Bollnow, summarizing the methodology of anthropological research, formulated four principles.

The first is the principle of anthropological reduction. Its essence is to separate the objective spheres of culture from man, since "all branches of culture... must be understood as dependent 
on the human needs due to which they exist and which they satisfy in human life" (transl. by O. G.) (Bollnow, 1996, p. 103).

Warning against the one-sidedness in his interpretation, the philosopher adds: "But as a methodological principle of philosophical anthropology, reduction does not mean the abolition or discredit of reality, but the return of discarded objectivity, and in this case also in relation to man and culture, their meaningful interconnection" (transl. by O. G.) (Bollnow, 1996, p. 104).

According to the second principle, one must separate man from objective images because "man as creator is tied to his own creation and is subject to it" (transl. by O. G.) (Plessner) (Bollnow, 1996, p. 104). Bollnow calls the second principle an organon-principle of anthropological research. And notes that both principles are complementary and interdependent, that is why they should be used together:

In the course of this operation we try to define one of the objective images of human culture, based on the understanding of man as his creator; on the other hand, we strive to understand a person based on what causes his or her formation. We also ask: can a man and to what extent, by his or her own nature, create art, science, politics, etc., according to his or her own internal need? What do we know from these creations about their creator? (transl. by O. G.) (Bollnow, 1996, p. 105)

The third principle of anthropological research is to help answer these questions - the principle of anthropological interpretation of individual phenomena of human life (Bollnow, 1996, p. 106).

First of all, it is about isolating any manifestation of human life that, for one reason or another, attracts special interest (fear, joy, shame (highlighted by me. - O. G.), work, holiday, etc.), and then - an attempt, on these grounds, to reach understanding of human as a whole, to some extent by extrapolating these manifestations, whereby they acquire the values necessary and sufficient for their function. (transl. by O. G.) (Bollnow, 1996, p. 106)

Such a phenomenon, "giving sharpness to the subject, separates one’s own human existence from everyday life; in view of this, there is only one single way - the way to the self through a radical break with the fluidity of daily existence". At the same time, the philosopher adds, "every single phenomenon has a direct relation to the understanding of man as a whole..." (transl. by O. G.) (Bollnow, 1996, p. 110). 
This provision implicates another principle of anthropological methodology, which another representative of philosophical anthropology (Helmuth Plessner) called "the principle of open question". The heuristic potential of the principle of open question is that it is a question "whose solution is not determined by its formulation; it is open to new unexpected and unpredictable answers" (transl. by O. G.) (Bollnow, 1996, p. 110).

\section{Problem statement}

Adhering to Dilthey's position that "one learns to know oneself not through direct selfobservation but only through self-objectification" (transl. by O. G.) (Bollnow, 1996, p. 105), let us try to apply the methodology and theoretical statements of philosophical anthropology to the analysis of visual self-objectifications - an artist. Such self-objectifications for an artist are works of fine art.

The aphoristic statement of another representative of the philosophical anthropology Max Scheler (1988): "...man is a creature that transcends himself and the world" (transl. by O. G.) is the best suited to characterize an Italian artist of the seventeenth century, Artemisia Gentileschi, the first woman in history to become a member of the Florence Academy of Fine Arts, which was also the first art academy in the world.

Her life and work come under another remarkable statement by Scheler (1994) that "a woman had a long time to gain herself as an individual" (transl. by O. G.).

I assume that each work by Artemisia Gentileschi is in one way or another its selfobjectification, and therefore the analysis of visual self-presentations in the artworks in diachronic dimension, which is carried out on the principle of anthropological reduction with the involvement of other principles of anthropological methodology, allows to trace the evolution of the artist's identity.

\section{Analysis of the references used}

The art of Artemisia Gentileschi (1593-1653) has become the object of much research in foreign art and cultural history in recent decades. Monographs, articles, and thesis papers dedicated to this extraordinary woman explored her life history and creativity. The intensity of the publications made it possible to speak of a kind of rediscovery after almost three centuries of her creative life.

Her works were analysed from the point of view of writing technique, in the context of creativity of the Caravaggesque painters, renaissance and baroque stylistics (Garrard, 1980, 1989; Locker, 2010, 2015; Robinson, 2017), attributions in the context of biographical data (Bissell, 1968, 1999; Cropper, 2001; Daugherty, 2015) (for example, the dedication of certain paintings to Galileo Galilei, with whom Artemisia Gentileschi was well acquainted and actively corresponded (Robinson, 2017, p. 130).

A. Gentileschi's work has been the subject of analysis from the perspectives of feminism (Barker, 2018) and psychoanalysis (Ferro, \& Civitarese, 2013), which is explained by the peculiarities of the artist's biography: her rape by Agostino Tassi, dating to May 1611, when Artemisia was 17 years old, as well as public disclosure and trial in March 1612.

In such circumstances, it is logical that psychoanalysis emphasized sexual as the foundations of her work, and feminism emphasized the gender characteristics of the society to which Artemisia belonged and which influenced her creativity. 
Unlike the previous ones, anthropological analysis proceeds from anthropological reductionism, when, apart from the above narratives, it is possible to reveal the artist's self-identity and its evolution, since the visual objectifications of the artist are not simply a result of the stimulusreaction principle (rape - a reaction to it) but the manifestation of a person who through selfobjectification in the works of painting recognizes herself as one that could be identified with her "self".

\section{Purpose}

Based on the anthropocentric approach to the analysis of visual self-presentations of Artemisia Gentileschi (paintings), to present her artwork as self-objectifications of the artist, which give rise to a new cultural reality and are at the same time a means of knowing the essence of man.

\section{Methodology}

The principles of philosophical and anthropological research were used when writing the article. Guided by the principle of anthropological reduction, the art of Artemisia Gentileschi was analysed as her self-objectification, the principle of extrapolation of an individual fact of the artist's life to the interpretation of her creativity, and the principle of anthropological interpretation of the evolution of creativity, when an attempt is made to know their creator through a series of chronological consistent works as figurative objectifications.

Iconographic and figurative stylistic methods (composition techniques, narrative, color characteristics) were used in the analysis of the art visuals and its classifications.

The analytical work was carried out in stages as transition from an iconographic interpretation of paintings with gradual elimination of art and style characteristics as extra-anthropological cultural constants with subsequent anthropological reduction of cultural image and anthropological interpretation of artwork evolution.

\section{Statement of basic materials}

Based on the theoretical and methodological stance of philosophical anthropology that creativity can always be seen in direct connection with the essence of man as a whole ("What do we learn from these creations about their creator?") (transl. by O. G.) (Bollnow, 1996, p. 105), let us try, through the analysis of creativity, to see the evolution of this essence, given the sometimes exceptional role of particular phenomena of the artist's life, which "can be viewed in direct connection with the essence of man as a whole" (transl. by O. G.) (Bollnow, 1996, p. 107).

Such a life fact of the Italian artist of the 17th century, the first woman to become a member of the Florence Academy of Fine Arts Artemisia Gentileschi, is undoubtedly a dramatic story of her rape.

In May 1611, when Artemisia was 17, she was raped by artist Agostino Tassi. In March 1612, the trial of Tassi began, lasting seven months.

Archival data regarding the trial of Tassi have been studied and partially published in the English translation by Mary Garrard (1989, p. 12). Also archival court documents were collected, researched and published by Patricia Cavazzini (2001).

It is known that Tassi was one of the artists who worked with Artemisia's father, Orazio Gentileschi. He undertook to teach the daughter of his colleague and friend a linear perspective. Under this guise, Tassi had the opportunity to be at Gentileschi's house. Although, according to 
court documents, in the absence of the father getting into the house was excluded: it was closed and it was possible to get into it if the door was opened by a member of household.

The testimony is a transcript of the court hearing, in which it was stated that in the father's absence Tassi was admitted into the house by one Tuzia, who lived with the two young children in the same house and who was either a friend, or a servant of Artemisia. On his admission, Tuzia led him to Artemisia, who at that time was drawing one of Tuzia's sons. Agostino Tassi told Tuzia to get out, while to Artemisia he said that she was not painting in the right way, he took her brushes away and offered to look at the painting, as an example, hanging in the bedroom.

As revealed during the investigation, Tuzia's role in this story was not limited to this episode. Earlier, she had invited Artemisia with her for walks, during which Tassi "unexpectedly" appeared and joined them.

In court, Tuzia stated that Tassi tortured her (?) until he was able to get to the part of the house where Artemisia lived.

Trying to get rid of the uninvited guest, Artemisia said she was feeling sick and had a fever. To which Tassi replied that his fever was even greater... Telling Artemisia that he wanted to look at the painting next to the bedroom, Tassi pushed her into the bedroom, locked the door from the inside, tossed her on the bed, closed the girl's mouth for her not to scream, and raped. Artemisia tried to defend herself: she scratched Agostino's face and head. After being raped, Artemisia freed herself, ran to the table where the knife was lying, and, with the words "I'll kill you for dishonouring me", struck Tassi with a knife into the chest. Although the blood came from the blow, no serious harm was done to the rapist.

Seeing that Artemisia was chaste, Tassi promised to marry her. Artemisia learned that he was already married only during the trial. Not only was Tassi married, but he had been serving a prison sentence twice. One for raping his wife, the other for raping her sister. When Tassi's wife suddenly disappeared, it was suggested that Tassi had hired the bandits to kill her.

Tassi's promise to marry kept Artemisia for some time from reporting the rape to her father (Artemisia's mother died when her daughter was 2 years old). However, Tassi was in no hurry to keep his promise. In doing so, he interfered with Artemisia's marriage with one Modenese, hiring men to spy on Artemisia almost round the clock, for he was very jealous of her without having any rights to her. Tassi's passion came in such wild forms that he told many people that he had poisoned Artemisia (details about this episode are unknown).

Finally, Orazio learned of the rape of his daughter and in the beginning of 1612 petitioned the Pope asking for legal proceedings. Not only Tassi, but also Cosimo Quorli, who also tried to court Artemisia, was indicted in court. In addition, Cosimo stole paintings from Artemisia's home, and was also accused of aiding Tassi to break into Gentileschi's house.

The trial was widely publicized. Tassi, trying to deflect the next prison sentence, initially denied not only the fact of Artemisia's rape, but also the fact that he had been in the Gentileschi's house. When, under pressure from evidence and testimony, he was forced to admit that it was untrue, he began to claim that he had visited the house and even followed Artemisia to "protect her honor." When this was denied, Tassi changed the tactics. He began to slander Artemisia, her dead mother, calling them all whores. Tassi claimed that Artemisia was sleeping with five different men at the same time, that she had an incest with her father, that he had somehow sold her for a loaf of bread, that there was a real brothel in the house. Tassi also attracted six men, his friends, who testified against Artemisia. These false witnesses were a match for Tassi himself. 
They "testified" that Artemisia's father sold her to men, that she served as a nude model to male artists, that she wrote erotic letters to various men and was a prostitute in general.

The slander and lies of Tassi were so horrific that, as the transcript of the trial shows, the judge, indignant at his slander, repeatedly interrupted the rapist and his crooks. Tuzia also testified in favour of Tussi; however, her testimony was only that Artemisia behaved too seductively.

There were also testimonies against Tassi. Giovanni Battista Stiattesi, who was a confidante of Tassi and Cosimo Quorli, which made his testimonies important, showed that Cosimo was very angry with Artemisia, who rejected his courtship. And also that he, Stiattezi, personally helped Tassi plan his break-in at Gentileschi's house when Orazio was not there.

The testimony of the virtue of Artemisia and the entire Gentileschi family was given by many people.

Artemisia herself testified under the tortures. In order to prove that she was telling the truth, she was subjected to physical tests by the so-called sibilli (thumbscrews) - a screw with ropes fastened to it, which bound the fingers of Artemisia. During the torture, the ropes were progressively wound onto the screw, tightening and actually breaking the fingers. Artemisia endured all the torture, during which she repeatedly said: "This is true", when asked whether Tassi had raped her. It is hard to imagine how painful these tortures were, it is known that they severely damaged her hands. But the moral pain of public humiliation from her abuser and the lawsuit itself was far greater.

On May 14, 1612, when Tassi had been imprisoned for more than a month, the judge heard Artemisia reiterating that she had trusted Tassi and would have never believed that Tassi, being a friend of her father, would have raped her.

The trial ended in October 1612, but due to the loss of the last part of the transcript of the court hearing, it is unknown what Tassi's sentence was.

Some authors believe that he was sentenced to spend eight months in prison after the trial, but was presumed to have been pardoned by a judge with an obligation to go to exile from Rome (the practice of punishment in the form of exile from the city was quite common in those times). But whether Tassi left Rome and for what period is not known for sure. He was known to be back in Rome soon.

Artemisia's father, Orazio, also sued six people for perjury, but the outcome of those lawsuits is unknown.

Even if the fact of rape was unknown, an analysis of the artist's works would suggest that the paintings with a recurring story (let us call them "lines" for this article) - appeared not simply to order, but are a form of the author's self-objectification, and their characters act as figurative carriers of the artist's self-identification.

The first "line" is five paintings on a biblical story about Judith and Holofernes. Most researchers interpret the paintings of this cycle as a manifestation of the artist's anti-masculine position, as symbolizing the motive of women's revenge on men. Unlike the biblical narrative, according to which a woman takes revenge not for herself, her honor and dignity, but for the interests of her people, and killing a man is not an act of revenge as on her personal abuser, but the destruction of a state or ethnic enemy.

In the painting "Judith beheading Holofernes" the personal color and actuality for the artist of this first version of the painting look obvious (the picture was painted just after or even during Tassi's trial). Judith decisively and even calmly cuts off with the sword Holofernes' head, supported by her maid, whose red dress creates a disturbing contrast to her mistress's blue dress. 
Blood from the neck of Holofernes flows down to the white sheet of the bed on which the death has found a sleeping man. R. L. Robinson draws attention to the artist's inexperience, which is manifested even in the elements of narrative visible in the genre scene. The composition reveals a significant physical inability of the woman to handle the weapon (Robinson, 2017, p. 151).

The second variant of the painting, with the same composition, but with a slightly modified modeling of the image of the main character and a different coloristic solution and much more "bloody" naturalism, was written in 1620. The "tragic" coloration (dress of the heroine of rich blue color, maid's red dress, brown background) of the first painting turns into a bright and almost festive one: a golden dress of Judith, a light olive-colored dress of the maid, white pillows and sheets, a bright red blanket covering Holofernes, whose blood this time is not just flowing on the sheets but spouts in different directions.

This is the apotheosis of revenge, so it is a joy and almost a holiday. (Which leads to the idea that even after eight years the artist's thirst for revenge did not go away). The festive nature of the event is emphasized even by the gold bracelet on the hand of Judith, whose face, unlike the first painting, acquires a more focused expression along with the resemblance to the face of the artist herself. Remembering that during the Middle Ages, gold symbolized holiness, the character of Judith acquires an additional positive semantics: the righteousness of her deed.

This variant - when the moment of decapitation of Holofernes is depicted - is rare in paintings. Usually, artists chose the moment after the decapitation of Holofernes. This is how Judith is represented by Giorgione, Botticelli, Mantegna, Cristofano Allori, Rubens, Klimt. Or until the beheading - "Judith" and "Judith and Holofernes" by Franz von Stuck.

Compositions of the subject post factum in the works of Artemisia Gentileschi are also presented: the first version was written almost immediately after the trial in 1613-1614, another one - 12 years later: in 1625. "Judith and her maid Abra with the head of Holofernes" (1650) in Capodimonte - moment after this bloody event.

Along with this cycle, another "line", not quantitatively less, is represented by works that objectifies the other side of the artist's "self". One that can be defined as sacrificial. It is a side of Artemisia's identity, which identifies her as a victim of sexual abuse.

It is about four paintings on the biblical story "Susannah and the Elders" on the courtship of the elders to a virtuous woman, whom they, having slandered, led to the threat of execution. Traditionally, the plot is interpreted as a total dependence of women in the male world: the shyness and weakness of women in front of men. Like her salvation, which also depends not on herself, but on another man.

An analysis of the "Susanna" line by Artemisia in chronological order reveals the evolution of the artist's personality in the direction of increasing her self-esteem.

In the 1610 painting, Susanna is full of shame, as evidenced by her posture. Trying to cover her naked body as fully as possible from the eyes of the brazen elders, she is bent almost in a circle, and the face expresses suffering, caused by feelings of shame and fear. It all shows that this woman is a victim.

Susanna in 1622 is also closed, but the circle is open: her head is raised, although the face retains the expression of torment. Unlike the previous two, Susanna in 1649 is active: she repels an arrogant old man. Her figure is three-quarter straightened to the abusers, and she does not burden herself with hiding her nakedness. The face expresses aversion and anger rather than shyness and fear. 
Susanna in the painting of 1652 is fully straightened to the elders, her left hand raised to the level of their faces as if she was ready to push them away. There is no shame on her face, rather anger and indignation. This Susanna is no longer ashamed and ready to physically stand up for herself.

In these paintings, not only the semantics of the image of Susannah itself evolves, the semantics of the composition as a whole changes. If in the first picture men hang over Susanna, which is a spatial sign of dominance, in the latter, Susanna's figure is almost on par with them, reducing their dominance.

For forty-two years, the artist was reproducing the story of Susanna and the Elders, constantly changing it in such a way that it gives grounds to argue: the evolution of the composition of the paintings and the treatment of the heroine poses objectify eliminating by Artemisia of psychotrauma, overcoming shame and fear as the ones, becoming external to herself and therefore liberation from them.

Some of the artist's self-portraits, including the "Self-Portrait as a Female Martyr" in 1615, should also be regarded as conditionally "sacrificial".

Self-portraiture as an artist's self-presentation is potentially the most informative about an artist's personality. However, like any self-presentation, self-portrait contains a significant social layer, reflecting the break through the author's identity of social excitations, assessments, specific historical ideas about the social status of man, etc.

The mentioned self-portraits of Artemisia Gentileschi were painted in the early years after an existential event, rape and trial, in the artist's life. They are dominated by the martyrdom motif, as evidenced by the names themselves, - the reflection of her own feelings that pervaded the young woman during this period.

The artist also portrayed herself in the image of Mary Magdalene. The Mary Magdalene motif is a repentance motif, and it is intensely objectified in the paintings for two decades after the notorious event in the artist's life: for example, in the 1620 painting.

This theme testifies that along with the motif of revenge (the semantics of the image of Judith as the punishment of a man) in the mind of Artemisia, the motif of repentance is not less important (the semantics of the image of Mary Magdalene as repentance of the woman herself).

The motif of guilt and its atonement is objectified in the images of Lucretia, in which it is not difficult again to recognize Artemisia herself: 1645. Lucretia (the semantics of Lucretia's image as punishment of the woman herself) is a symbol of atonement for sin, which was not initiated by the woman. At the same time, it is "refraction" in the self-awareness of the artist of a socially imposed evaluation stereotype.

However, if the first two paintings portray the image of Lucretia, who would immediately commit suicide for the sake of restoring her good name, then the 1645 version is written on the story of the rape itself, emphasizing the innocence of the woman and shifting social condemnation to the man.

All the analyzed lines of artistic objectification of Artemisia Gentileschi's personality can be considered milestones in the transformation of her anthropological essence, they represent the gradual liberation from juvenile psycho-trauma and the formation of a new identity of the artist, who went through the gradual suppression of the revenge motif and the removal of feelings of shame, guilt and repentance imposed by the social evaluation stereotypes. 


\section{Originality}

Originality consists in the author's method of analysing the works of visual art in terms of anthropocentric approach, as well as in considering the artwork by Artemisia Gentileschi as her self-objectification as such that give rise to a new cultural reality.

\section{Conclusions}

The artworks by Artemisia Gentileschi in diachronic deployment can be seen as the painter's self-objectification, which traces the evolution of self-expression from a person with traditional self-perception by social gender stereotypes (1610) to the phenomenon of personal life, which will determine further evolution of her self-identification (rape in 1611) and extirpation of sense of shame through virtual revenge (self-expression in the cycle of Judith), repentance (cycle of Mary Magdalene), guilt (cycle of Lucretia), and formation of component of the painter's identity as exemption from social gender prejudices and stereotypes on roles and standards of behaviour socially assigned to women - shyness and fear in relation to a man (cycle of Susanna).

\section{REFERENCES}

Barker, S. (2018). The First Biography of Artemisia Gentileschi: Self-fashioning and Proto-feminist Art History in Cristofano Bronzini’s Notes of Women Artists. Mitteilungen Des Kunsthistorischen Institutes in Florenz, 60(3), 404-435. (in English)

Bissell, R. Ward. (1968). Artemisia Gentileschi-A New Documented Chronology. The Art Bulletin, 50(2), 153-168. DOI: https://doi.org/10.2307/3048529 (in English)

Bissell, R. Ward. (1999). Artemisia Gentileschi and the Authority of Art: Critical Reading and Catalogue Raisonne. PA: Pennsylvania State University Press. (in English)

Bollnow, O. F. (1996). Die philosophische Anthropologie und ihre methodischen Prinzipien. A. Hordiienko, Trans. from German. In V. V. Liakh, \& V. S. Pazenok, Suchasna zarubizhna filosofiia. Techii i napriamy: Khrestomatiia (pp. 96-111). Kyiv: Vakler. (in Ukrainian)

Cavazzini, P. (2001). Documents Relating to the Trial of Agostino Tassi. In J. P. O’Neill (Ed.), Orazio and Artemisia Gentileschi (pp. 432-444). New York: Metropolitan Museum of Art. (in English)

Cropper, E. (2001). Life on the Edge: Artemisia Gentileschi, Famous Women Painter. In J. P. O’Neill (Ed.), Orazio and Artemisia Gentileschi (pp. 262-281). New York: Metropolitan Museum of Art. (in English)

Daugherty, B. (2015). Between Historical Truth and Story-Telling: The Twentieth-Century Fabrication of "Artemisia". University of Nebraska-Lincoln. (in English)

Ferro, A., \& Civitarese, G. (2013). Analysts in Search of an Author: Voltaire or Artemisia Gentileschi? Commentary on "Field Theory in Psychoanalysis, Part 2: Bionian Field Theory and Contemporary Interpersonal/Relational Psychoanalysis" by Donnel B. Stern. Psychoanalytic Dialogues, 23(6), 646-653. DOI: https://doi.org/10.1080/10481885.2013.851549 (in English)

Garrard, M. D. (1980). Artemisia Gentileschi’s Self-Portrait as the Allegory of Painting. The Art Bulletin, 62(1), 97-112. DOI: https://doi.org/10.2307/3049963 (in English)

Garrard, M. D. (1989). Artemisia Gentileschi: The Image of the Female Hero in Italian Baroque Art. Princeton University Press. (in English)

Locker, J. (2010). An Eighteenth-Century Biography of Artemisia Gentileschi. Source: Notes in the History of Art, 29(2), 27-37. DOI: https://doi.org/10.1086/sou.29.2.23208613 (in English)

Locker, J. M. (2015). Artemisia Gentileschi: The Language of Painting (pp. 3-5). Yale University Press. (in English)

Robinson, R. L. R. (2017). Wonder Women: Sofonisba Anguissola, Lavinia Fontana and Artemisia Gentileschi. A Critical Analysis of Renaissance and Baroque Self-Portrait Painting by Female Artists. Italy: Studio Art Centers International Florence. (in English)

Scheler, M. (1988). Die Stellung des Menschen im Kosmos. A. Filippov, Trans. In Problema cheloveka v zapadnoy philosophii (pp. 31-95). Moscow: Progress. (in Russian)

Scheler, M. (1994). Der Formalismus in der Ethik und die Materiale Wertethik. In Izbrannye proizvedeniya (pp. 259-338). Trans. from German. Moscow: Gnozis. (in Russian)

Creative Commons Attribution 4.0 International

doi: https://doi.org/10.15802/ampr.v0i17.206728

(C) O. M. Goncharova, 2020 


\section{LIST OF REFERENCE LINKS}

Barker S. The First Biography of Artemisia Gentileschi: Self-fashioning and Proto-feminist Art History in Cristofano Bronzini's Notes of Women Artists. Mitteilungen Des Kunsthistorischen Institutes in Florenz. 2018. Vol. 60. No. 3. P. 404-435.

Bissell R. Ward. Artemisia Gentileschi-A New Documented Chronology. The Art Bulletin. 1968. Vol. 50. No. 2. P. 153-168. DOI: https://doi.org/10.2307/3048529

Bissell R. Ward. Artemisia Gentileschi and the Authority of Art: Critical Reading and Catalogue Raisonne. PA : Pennsylvania State University Press, 1999. 446 p.

Больнов О. Ф. Філософська антропологія та ії методичні принципи / пер. 3 нім. А. Гордієнка. Сучасна зарубіжна філософія. Течії і напрями : хрестоматія / упоряд. В. В. Лях, В. С. Пазенок. Київ : Ваклер, 1996. C. 96-111.

Cavazzini P. Documents Relating to the Trial of Agostino Tassi. Orazio and Artemisia Gentileschi / ed. by J. P. O’Neill. New York : Metropolitan Museum of Art, 2001. P. 432-444.

Cropper E. Life on the Edge: Artemisia Gentileschi, Famous Women Painter. Orazio and Artemisia Gentileschi / ed. by J. P. O’Neill. New York : Metropolitan Museum of Art, 2001. P. 262-281.

Daugherty B. Between Historical Truth and Story-Telling: The Twentieth-Century Fabrication of "Artemisia". University of Nebraska-Lincoln, 2015. 117 p.

Ferro A., Civitarese G. Analysts in Search of an Author: Voltaire or Artemisia Gentileschi? Commentary on "Field Theory in Psychoanalysis, Part 2 : Bionian Field Theory and Contemporary Interpersonal/Relational Psychoanalysis" by Donnel B. Stern. Psychoanalytic Dialogues. 2013. Vol. 23. Iss. 6. P. 646-653. DOI: https://doi.org/10.1080/10481885.2013.851549

Garrard M. D. Artemisia Gentileschi’s Self-Portrait as the Allegory of Painting. The Art Bulletin. 1980. Vol. 62. No. 1. P. 97-112. DOI: https://doi.org/10.2307/3049963

Garrard M. D. Artemisia Gentileschi: The Image of the Female Hero in Italian Baroque Art. Princeton University Press, 1989. $664 \mathrm{p}$.

Locker J. An Eighteenth-Century Biography of Artemisia Gentileschi. Source: Notes in the History of Art. 2010. Vol. 29. Iss. 2. P. 27-37. DOI: https://doi.org/10.1086/sou.29.2.23208613

Locker J. M. Artemisia Gentileschi: The Language of Painting. Yale University Press, 2015. P. 3-5.

Robinson R. L. R. Wonder Women: Sofonisba Anguissola, Lavinia Fontana and Artemisia Gentileschi. A Critical Analysis of Renaissance and Baroque Self-Portrait Painting by Female Artists. Italy : Studio Art Centers International Florence, 2017. 244 p.

Шелер М. Положение человека в Космосе / пер. А. Филиппова. Проблема человека в западной философии. Москва : Прогресс, 1988. С. 31-95.

Шелер М. Формализм в этике и материальная этика ценностей. Избранные произведения. Москва : Гнозис, 1994. C. 259-338.

\section{О. М. ГОНЧАРОВА ${ }^{1 *}$}

\footnotetext{
${ }^{1 *}$ Київський національний університет культури і мистецтв (Київ, Україна), ел. пошта o.m_goncharova@yahoo.com, ORCID 0000-0002-8649-9361
}

\section{АНТРОПОЛОГІЯ ВІЗУАЛЬНОЇ САМООБ'СКТИВАЦІЇ ХУДОЖНИКА (НА МАТЕРІАЛІ ТВОРІВ АРТЕМІЗІЇ ДЖЕНТІЛЕСКІ)}

Мета. На основі антропоцентричного підходу до аналізу візуальних самопрезентацій Артемізії Джентілескі у творах живопису представити художню творчість як самооб'єктивації мисткині, що, породжуючи нову культурну реальність, виступають водночас засобами пізнання сутності людини. Теоретичний базис. При написанні статті використано принципи і методи філософсько-антропологічного дослідження у поєднанні з хронологічним, іконографічним і образно-стилістичним методами. 3 поміж філософсько-антропологічних використовувався принцип антропологічної редукції, керуючись яким аналізувалась творчість Артемізії Джентілескі як ії самооб’єктивація, принцип екстраполяції окремого факту життя художниці та антропологічної інтерпретації еволюції творчості, коли крізь низку хронологічно 
послідовних творів як образних об'єктивацій, здійснюється спроба пізнання їхнього творця. Іконографічні та образно-стилістичні методи (прийоми композиції, сюжети, колористичні характеристики) - при аналізі художнього відеоряду: автопортретів, алегорій і сюжетних картин. Аналітична робота здійснювалась поетапно як перехід від іконографічної інтерпретації картини 3 поступовою елімінацією художньостильових характеристик як позаантропологічних культурних констант із подальшою антропологічною редукцією культурного образу. Наукова новизна полягає в авторській методиці аналізу творів візуального (образотворчого) мистецтва 3 точки зору антропоцентричного підходу, а також у розгляді художньої творчості Артемізії Джентілескі як ії самооб'єктивацій як таких, що, породжуючи нову культурну реальність, виступають водночас засобами пізнання сутності людини. Висновки. Творчість Артемізії Джентілескі в діахронічному розгортанні можна розглядати як самооб'єктивацію художниці, в якій простежується еволюція самовиявлення від особистості з традиційним самосприйняттям за соціальними гендерними стереотипами (1610р.) до феномену особистого життя, який визначатиме подальшу еволюцію іiі самоідентифікування (згвалтування 1611 р.) та викорінення почуття сорому через віртуальну помсту (самовиявлення в циклі Юдиф), каяття (цикл Марії Магдалини), провини (цикл Лукреції) та формування складової ідентичності художниці як звільнення від соціальних гендерних забобонів і стереотипів щодо соціально приписаних жінці ролей і стандартів поведінки (цикл Сусанни).

Ключові слова: Артемізія Джентілескі; самооб’єктивація художника; візуальні самопрезентації в творах живопису; антропоцентричний підхід; людина; принцип антропологічної редукції; органон-принцип; антропологічна інтерпретація; принцип "відкритого питання"

\section{Е. Н. ГОНЧАРОВА ${ }^{1 *}$}

${ }^{1 *}$ Киевский национальный университет культуры и искусств (Киев, Украина), эл. почта o.m_goncharova@yahoo.com, ORCID 0000-0002-8649-9361

\section{АНТРОПОЛОГИЯ ВИЗУАЛЬНОЙ САМООБЪЕКТИВАЦИИ ХУДОЖНИКА (НА МАТЕРИАЛЕ ПРОИЗВЕДЕНИЙ АРТЕМИЗИИ ДЖЕНТИЛЕСКИ)}

Цель. На основе антропоцентрического подхода к анализу визуальных самопрезентаций Артемизии Джентилески в произведениях живописи представить художественное творчество как самообъективации художницы, которые, порождая новую культурную реальность, выступают одновременно способами познания человека. Теоретический базис. При написании статьи использовано принципы и методы философскоантропологического исследования в соединении с хронологическим и образно-стилистическим методами. Из философско-антропологических использовался принцип антропологической редукции, руководствуясь которым анализировалось творчество Артемизии Джентилески, как ее самообъективация. Принцип экстраполяции отдельного факта (изнасилования) жизни художницы и антропологической интерпретации эволюции творчества, когда через ряд хронологически последовательных произведений как образных объективаций осуществлялась попытка познания их творца. Биографический метод использовался при работе с данными о жизни художницы, иконографический и образно-стилистический (приемы композиции, сюжеты, колористические характеристики) - при анализе художественного видеоряда: автопортретов, аллегорий, сюжетных картин. Аналитическая работа осуществлялась поэтапно как переход от иконографической интерпретации картин с постепенной элиминацией художественно-стилистических характеристик как внеантропологических культурных констант с последующей антропологической редукцией культурного образа. Научная новизна заключается в авторской методике анализа произведений визуального (изобразительного) искусства с точки зрения антропоцентрического подхода, а также в рассмотрении художественного творчества Артемизии Джентилески как ее самообъективаций, порождающих новую культурную реальность. Выводы. Творчество Артемизии Джентилески в диахроническом развертывании можно рассматривать как самообъективацию художницы, в которой прослеживается эволюция самовыявлення от личности с традиционным самовосприятием, согласно социальным гендерным стереотипам (1610 г.) до феномена личной жизни, который будет определять дальнейшую эволюцию ее самоидентификации (изнасилование 1611 г.) и изживания чувства стыда через виртуальную месть (самовыявление в цикле Юдифи), раскаяния (цикл Марии Магдалины), вины (цикл Лукреции) и формирования составных идентичности художницы, как осво- 
бождения от социальных гендерных предрассудков и оценочных стереотипов относительно социально предписанных женщине ролей и типов поведения (цикл Сусанны).

Ключевые слова: Артемизия Джентилески; самообъективация художника; визуальные самопрезентации в произведениях живописи; антропоцентрический подход; человек; принцип антропологической редукции; органон-принцип; антропологическая интерпретация; принцип "открытого вопроса"

Received: 07.11.2019

Accepted: 11.05 .2020 